Denise Levertov

\title{
Czynienie pokoju
}

DOI: http://dx.doi.org/10.12775/LC.2017.010

Głos z ciemności zawołał:

$$
\text { „Poeci muszą dać nam }
$$

wyobraźnię pokoju, która wyprze silną, dobrze nam znaną

wyobraźnię katastrofy. Pokój, a nie tylko

brak wojny".

Ale pokój, tak samo jak wiersz,

nie istnieje przed samym sobą,

nie może być wyobrażony zanim powstanie,

nie może być poznany inaczej niż

w słowach swojego powstawania,

gramatyce sprawiedliwości,

syntaktyce wzajemnej pomocy.

Uczucie ku niemu,

niejasno przewidujące rytm, to wszystko, co mamy,

dopóki nie zaczniemy wypowiadać jego metafor,

ucząc się, gdy mówimy.

Linijka pokoju mogłaby się pojawić,

gdybyśmy zmienili strukturę zdania, które powstaje z naszego życia,

unieważnili jego potwierdzenia dla zysku i władzy,

zakwestionowali nasze potrzeby, pozwolili na

długie przerwy...

Kadencja pokoju mogłaby zrównoważyć jego ciężar

na innym punkcie podparcia; pokój, obecność,

pole energetyczne silniejsze niż wojna,

mógłby wtedy pulsować,

zwrotka za zwrotką w świat,

każdy akt życia

jedno z jego słów, każde słowo

wibracja światła - ścianki

tworzącego się kryształu. 